\title{
Presentation of the Dossier
}

We are pleased to offer our readers a brief about The contributions of archaeological research in literary approaches to the Bible, an effort to honor our commitment to scientific theological production, in this case engaging a science whose unique contribution has enriched and continues to enrich our knowledge of Biblical lands and times, providing us with important comparative material to our own times and circumstances. For this reason, the article chosen to open these considerations is "Brief history of biblical archeology: contribution and american criticism", by Fábio Augusto Darius and Elder Hosokawa, in which these researchers show the affinities of Biblical archaeology with archaeological science in general, and devote themselves to the ambitious goal of relating, even if briefly, the main names and events of Biblical archaeology from its origin to the present, as well as present important aspects of the American contribution to the research, dissemination, and criticism of Biblical archaeology.

After this initial contextualization concerning Biblical archaeology, the article "Archeology of the ancient Near East in Brazil: the Museum of Biblical Archeology of the Adventist University Center of São Paulo and its collection", by Valéria Marques dos Santos Tavares and Claudia Rodrigues Ferreira de Carvalho, points out to the relationship between Biblical archaeology and museum collections, taking as its case study the only museum of Biblical archaeology in Latin America, and analyzes its characteristics, heritage, potentialities, weaknesses and intents.

Another article that addresses the problem of silence is "In the dark, archaeologists like to stay in silence: the argument of silence and the historicity of Pilate's pardon to Barabbas", by Milton L. Torres, who evaluates the strength of the so-called arguments of silence, showing some of their advantages and pitfalls. In doing so, the author revisits the few historical references to a supposed ancient custom in which a prisoner receives clemency due to the celebration of some religious festival.

The fourth article "The art of irony in the New Testament", by Antonio Carlos Soares dos Santos, has less archaeological resonance and offers a more literary flavor. Nevertheless, it offers an equally interesting treatment 
regarding the use of irony in the New Testament, especially in the context of euphemism and hyperbole. Its value comes precisely from the demonstration that texts considered sacred can also use conventional rhetorical strategies to establish their point of view.

Finally, we close this brief with the article "Rethinking the ancient literature: the inscription as production of presence and artwork", by João Batista Ribeiro Santos. It is an approach to ancient literature, "for the sake of anthropological archaeology", through epigraphy, especially focused on the artistic and aesthetic dimensions of the craftsmanship that was necessary to produce the ancient inscriptions.

We therefore congratulate the authors for their invaluable contribution to scientific theology, and invite readers to examine, with care and favor, the select texts included here, in the hope that, once again, the journal Caminhando fulfill its role of disseminating knowledge and fostering dialogue.

Prof. Dr. Milton L. Torres

Coordenador de Letras/Tradutor \& Intérprete do Centro Universitário Adventista (UNASP)

Dossier's coordinator 